\title{
Synthesis and Characterization of a New Compound of Cobalt II with Isonicotinamide and Evaluation of the Bactericidal Potential
}

\author{
Anderson Dourado Galvão*, Fabricio Tarso de Moraes, Claudia Cristina de Sousa, \\ Kátia Meirelles Duarte de Sousa, Patrícia Gelli Feres de Marchi, \\ Adenilda Cristina Honorio França, Eduardo Luzía França, Wagner Batista dos Santos* (i) \\ Federal University of Mato Grosso-Barra do Garças/MT, Brazil \\ Email: *andersondourado03@gmail.com, *wbsantos@ufmt.br
}

How to cite this paper: Galvão, A.D., De Moraes, F.T., De Sousa, C.C., De Sousa, K.M.D., De Marchi, P.G.F., França, A.C.H., França, E.L. and Dos Santos, W.B. (2019) Synthesis and Characterization of a New Compound of Cobalt II with Isonicotinamide and Evaluation of the Bactericidal Potential. Open Journal of Inorganic Chemistry, 9, 11-22.

https://doi.org/10.4236/ojic.2019.92002

Received: March 23, 2019

Accepted: April 25, 2019

Published: April 28, 2019

Copyright ( 2019 by author(s) and Scientific Research Publishing Inc. This work is licensed under the Creative Commons Attribution International License (CC BY 4.0).

http://creativecommons.org/licenses/by/4.0/

\section{(c) (i) Open Access}

\begin{abstract}
In this work, the isonicotinamide was coordinated to the Cobalt ion in oxidation state +2 . The relevance of this work is the investigation of the in vitro bactericidal potential of the synthesized complex when tested in Gram-positive and negative bacteria strains. This study is motivated by the need to obtain new materials that have antibiotic properties and that, in the future, may become an effective drug against resistant bacteria. A new coordination compound of Cobalt and isonicotinamide, $\left[\mathrm{Co}\left(\mathrm{H}_{2} \mathrm{O}\right)(\mathrm{isn})_{3}\right]\left(\mathrm{BF}_{4}\right)_{2}$, was synthesized and described. The compound was characterized by thermoanalytical techniques TG-DTG and TG-DSC, where it was possible to propose the mechanism of thermal decomposition. Through the spectroscopy in the region of the medium infrared (FTIR), it is possible to infer the site of connection between isonicotinamide and metal. The bactericidal activity of $\left[\mathrm{Co}\left(\mathrm{H}_{2} \mathrm{O}\right)(\mathrm{isn})_{3}\right]\left(\mathrm{BF}_{4}\right)_{2}$, $\mathrm{CoCl}_{2}$ and free Isonicotinamide were tested for the bacteria Streptococcus mutans (Gram+) and Escherichia coli (Gram-) and the synthesized compound showed to be sensitive for both bacteria.
\end{abstract}

\section{Keywords}

Cobalt, Isonicotinamide, Spectroscopy Infrared, TG/DTG and TG/DTA, Bactericidal Activity

\section{Introduction}

Bacteria have been present on Earth for billions of years, and to survive the environment, they have developed adaptive mechanisms that have allowed them to resist natural medicines for all that time [1]. The discovery of active antimicrobial principles, later used as antibiotics, has been an important tool for in- 
creasing longevity and quality of human life [2].

The discovery of penicillin in mid-1928 [1] boosted the search for new drugs and large numbers of antibiotics were described and reported until 1939 and in subsequent decades [2]. Man's constant struggle with the microbial environment has increased over the years, in the same way as has the use of antibiotics in an indiscriminate and incorrect way [3]. The ease in acquiring this type of substance, either naturally or through the pharmaceutical industry has caused the bacteria to develop mechanisms of resistance to these drugs [4]. The seriousness of this problem is worldwide and in May 2015 the World Health Organization approved a set of measures called the Global Plan of Action on Microbial Resistance [4], which sets out five general objectives: 1) Improve awareness and understanding of antimicrobial resistance through communication, education and effective training; 2) Strengthen the knowledge base and evidence through surveillance and research; 3 ) Reduce the incidence of infection through effective sanitation, hygiene and infection prevention measures; 4) Optimize the use of antimicrobial drugs in human and animal health; 5) Develop the economic argument for sustainable investment that considers the needs of all countries, and increases investment in new medicines, diagnostic tools, vaccines and other interventions [4].

Analyzing topic five of the Global Plan of Action on Microbial Resistance, there is a need for investments in new drugs, given that current antibiotics have a declining clinical life as soon as they are put on the market [3] [4]. Numerous studies, involving organic molecules with natural or synthetic biological activities coordinated to metals to intensify their properties, showed that the use of coordination compounds may be an alternative to the use of the drug in its free form as a medicine [5]-[13].

Studies such as by Asegbeloyin et al. [12] showed that compounds of cobalt (II) and other transition metals had higher bactericidal activity than imines in their free state. Tawfik et al. [13] Studied the biological activity of compounds containing $\mathrm{Co}^{2+}, \mathrm{Zn}^{2+}$ and $\mathrm{Sn}^{2+}$ and showed that the coordination to the metallic centers resulted in an increase in the antimicrobial activity: $\mathrm{Co}^{2+}>\mathrm{Zn}^{2+}>\mathrm{Sn}^{2+}$.

Studies that focus on the use of ligands coordinated to metals for use as bactericides consider that this type of interaction (metal-ligand) can present distinct toxicological and pharmacological characteristics, which may favor the reduction of side effects [14].

This study aimed to develop and characterize a new complex formed by the coordination of cobalt (II) isonicotinamide, and to perform a qualitative study of the potential bactericidal activity of the synthesized complex, tested in vitro on Streptococcus mutans (S. mutans) Gram (+) and Escherichia coli (E. coli) Gram $(-)$.

\section{Experimental}

\subsection{Materials}

Cobalt(II) chloride, p.a., anhydrous, $\geq 98.0 \%$ (Sigma-Aldrich); 
Isonicotinamide, p.a, 99\% (Sigma-Aldrich);

Zinc, granular, 30 - 100 mesh, 99\% (Sigma-Aldrich);

Sodium Tetrafluoroborate, 99\% (Sigma-Aldrich);

MUELLER-HILTON AGAR (OXOID).

\subsection{Synthesis of Compound}

$0.4804 \mathrm{~g}(0.0037 \mathrm{~mol})$ of $\mathrm{CoCl}_{2}$ were solubilized in $5 \mathrm{ml}$ of distilled water, then immediately $1.3556 \mathrm{~g}$ of isonicotinamide $(0.0111 \mathrm{~mol})$ were dissolved in $10 \mathrm{~mL}$ of the same solvent and added to the beaker containing the cobalt(II) chloride solution. To this mixture, zinc amalgam [15] was added and placed under constant stirring for $1.5 \mathrm{~h}$. Thereafter, the resulting solution was filtered and to the supernatant was added $0.8125 \mathrm{~g}$ of $\mathrm{NaBF}_{4}(0.0074 \mathrm{~mol})$, dissolved in $1 \mathrm{ml}$ of distilled water. Finally, the mixture was refrigerated in an ice bath, and after 4 days the precipitate was filtered and put in a desiccator. Average yield: $70 \%$.

\subsection{Characterization}

The determination of the stoichiometry of the compound was performed through minimal calculation formula from the thermogravimetric curve, as well as by studying the thermal behavior. The complex salt was also characterized by spectroscopy in the medium-infrared region, and by solubility tests and other qualitative tests. Thermoanalytical Techniques: The TG/DTG and TG-DSC curves were obtained on Mettler Toledo TGA/DSC 1 equipment. The system was calibrated following the specifications provided by the manufacturer. The analyses were obtained in $\alpha-\mathrm{Al}_{2} \mathrm{O}_{3}$ crucible $(70 \mu \mathrm{L})$, with a sample mass of approximately $5 \mathrm{mg}$, a heating rate of $20^{\circ} \mathrm{C} \cdot \mathrm{min}^{-1}$, in dry air at $60 \mathrm{~mL} \cdot \mathrm{min}^{-1}$ flow and range temperature of $30^{\circ} \mathrm{C}-1000^{\circ} \mathrm{C}$. Medium FT-IR Infrared Spectroscopy: The spectra in the infrared region were acquired in a Perkin Elmer Model 100 Fourier transform spectrometer, with a resolution of $4 \mathrm{~cm}^{-1}$ in the region $4000 \mathrm{~cm}^{-1}-600 \mathrm{~cm}^{-1}$ using the reflectance accessory for attenuated total reflection technique (ATR) with germanium crystal (Ge).

\subsection{Microorganisms and Controls}

The microorganisms used in the assays were enteropathogenic, E. coli and $S$. mutans, both provided by the ATCC (American Type Culture Collection). The antibiotic used as a positive control was gentamicin $10 \mu \mathrm{g} /(\mathrm{G} 5427)$ manufactured in July 2016, provided by Sensifar.

\subsection{Lineage and Culture of $S$, mutans}

S. mutans (ATCC ${ }^{\oplus} 25175^{\mathrm{TM}}$ ) was used and stored at $-70^{\circ} \mathrm{C}$. The stock culture was maintained in semi-solid agar in the absence of light. From this stock culture 24 hours before the test, subcultures were performed in tubes containing $8 \mathrm{ml}$ TSB (Trypic Soy Broth-DIFCO) and incubated in an incubator at $37^{\circ} \mathrm{C}$ for $24 \mathrm{~h}$. 


\subsection{Lineage and Culture of E. coli.}

E. coli (EPEC) serotype O111: $\mathrm{H}-\mathrm{Al}-$, eae+, eaf + , bfp+ was used, conserved at $70^{\circ} \mathrm{C}$. The stock culture was maintained in semi-solid agar in the absence of light. From this stock culture $24 \mathrm{~h}$ before the test, subcultures were performed in tubes containing $8 \mathrm{ml}$ TSB (Trypic Soy Broth - DIFCO) and incubated in an incubator at $37^{\circ} \mathrm{C}$ for $24 \mathrm{~h}$.

\subsection{Disk and Well Technique: Müller-Hinton Agar Medium}

The preparation of the Müller-Hinton agar medium was made according to the Clinical and Laboratory Standards Institute (CLSI) [16] and the disk and well technique was performed according to the same, with adaptations. In the antimicrobial assays, plaques were inoculated with the $S$. mutans and $E$. coli bacteria, wells were prepared for each active ingredient alone $\left(\mathrm{CoCl}_{2},\left[\mathrm{Co}\left(\mathrm{H}_{2} \mathrm{O}\right)(\mathrm{isn})_{3}\right]\left(\mathrm{BF}_{4}\right)_{2}\right.$ and isonicotinamide). A gentamicin disk was used as a positive control for both bacteria. In the Petri dishes, with the solid medium already inoculated with the microorganisms, wells were prepared to receive the material to be analyzed. The masses used in the analyses were $0.0210 \mathrm{~g} \mathrm{CoCl}_{2}, 0.1000 \mathrm{~g}\left[\mathrm{Co}\left(\mathrm{H}_{2} \mathrm{O}\right)(\mathrm{isn})_{3}\right]\left(\mathrm{BF}_{4}\right)_{2}$ and $0.0593 \mathrm{~g}$ isonicotinamide, equivalent to the stoichiometric ratio of 1:1:3 mol. The readings were made after $48 \mathrm{~h}$ and the results of the analyses were expressed as a function of the diameter of the inhibition halos, in millimeters, with the aid of a ruler.

\section{Results and Discussions}

\subsection{Thermoanalytical Techniques}

In the curves referring to the TG-DTG and TG-DSC analyses of isonicotinamide in its free form, it can be observed in Figure 1 that it presented a single mass-loss step $\left(160^{\circ} \mathrm{C}-290^{\circ} \mathrm{C}\right)$ with the probable maximum loss rate at $282^{\circ} \mathrm{C}$. Three peaks can be seen in DSC, where the first refers to the polymorphic transition at about $120^{\circ} \mathrm{C}$ [17] [18] and the second and third peaks indicate fusion followed by evaporation.

The thermal decomposition steps of the compound $\left[\mathrm{Co}\left(\mathrm{H}_{2} \mathrm{O}\right)_{\mathrm{x}}(\mathrm{isn})_{\mathrm{y}}\right]\left(\mathrm{BF}_{4}\right)_{z}$ can be seen in Table 1. As can be seen, the synthesized compound exhibited thermal stability up to $118^{\circ} \mathrm{C}$ and showed five consecutive mass losses.

All thermal decomposition steps were followed by endothermic peaks of DSC which indicate that there was no oxidative degradation of the material.

In order to propose a thermal decomposition mechanism, the material was flame tested, where it was initially macerated and then placed in a test tube. With the aid of a mercury thermometer up to $300^{\circ} \mathrm{C}$, it was possible to monitor the thermal behavior of the compound. The sprayed material was a pink/reddish color and after being heated to about $120^{\circ} \mathrm{C}$ the complex salt became violet; this first change is attributed to the loss of coordinated water.

At $170^{\circ} \mathrm{C}$ a gas was released, and the test tube was removed from the plate. The gas crystallized on the wall of the test tube; it was initially thought to be free 

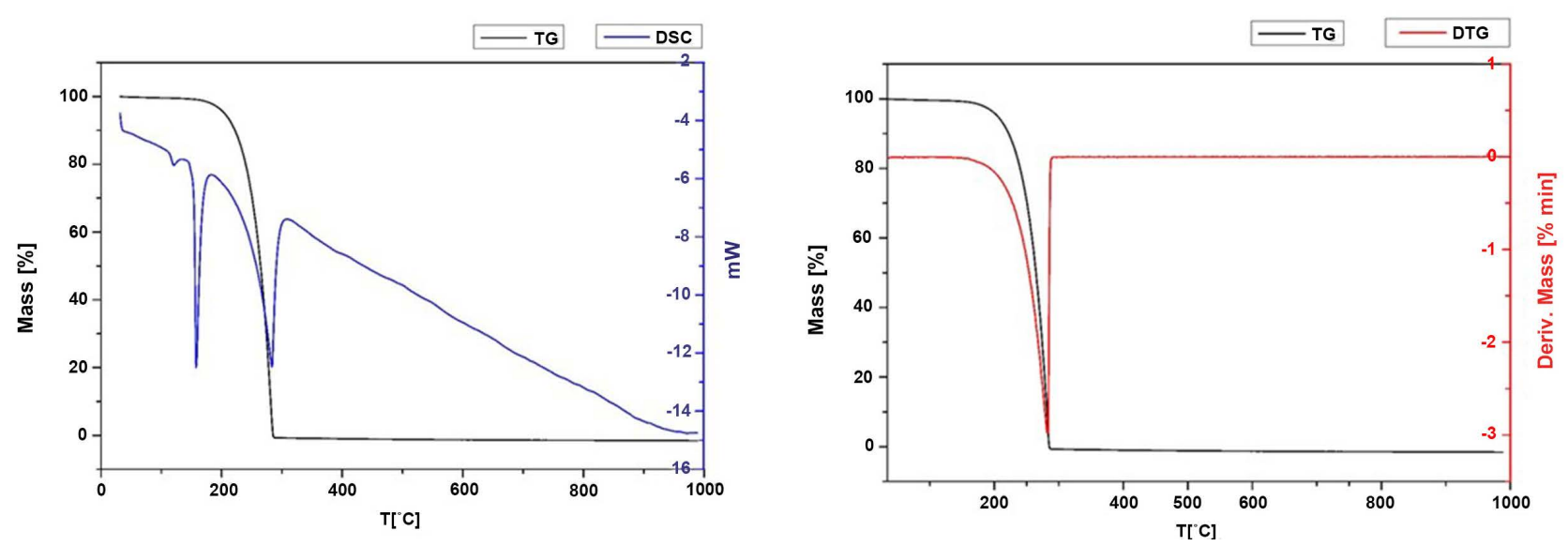

Figure 1. TG-DSC and TG-DTG of isonicotinamide.

Table 1. Thermal decomposition stages.

\begin{tabular}{cccccc}
\hline$\left[\mathrm{Co}\left(\mathrm{H}_{2} \mathrm{O}\right)_{\mathbf{x}}(\mathrm{isn})_{\mathbf{y}}\right]\left(\mathrm{BF}_{4}\right)_{\mathbf{z}}$ & \multicolumn{5}{c}{ Stages } \\
\hline $\mathrm{T}{ }^{\circ} \mathrm{C}$ & $118-155$ & $170-260$ & $270-330$ & $330-380$ & $830-930$ \\
$\Delta \mathrm{m} \%$ & 4.4460 & 32.2399 & 30.2311 & 9.7562 & 10.7721 \\
Peaks & $141^{\circ} \mathrm{C} /$ endo. & $248^{\circ} \mathrm{C} /$ endo. & $306^{\circ} \mathrm{C} /$ endo. & $370^{\circ} \mathrm{C} /$ endo. & $917^{\circ} \mathrm{C} / \mathrm{endo}$. \\
\hline
\end{tabular}

isonicotinamide because it was a white crystalline solid. This solid was removed from the whole assay and the material studied by infrared spectroscopy. The infrared spectrum of the free isonicotinamide (A) and the test tube residue (B) can be seen in Figure 2.

In the interval $270^{\circ} \mathrm{C}-280^{\circ} \mathrm{C}$ there was the appearance of a yellowish gas that was probably the formation of $\mathrm{NO}_{2(\mathrm{~g})}$; however, it is not possible to say whether this gas came from the $-\mathrm{NH}_{2}$ of the amide group or from the nitrogen of the pyridine ring. Soon thereafter, the material melted to an azure blue hue (gas formation and melting occurred almost simultaneously).

At higher temperatures, it was not possible to keep up with the thermometer. Soon after the melting, the material kept the blue tone, and it was no longer possible to observe changes. After the material cooled, a solution of silver nitrate was added to the test tube, and a whitish solid appeared, which is attributed to cobalt tetrafluoroborate.

Analyzing Figure 2, it can be stated that the FTIR spectra of isonicotinamide in its free state (A) and of the crystallized white solid in the wall of the whole test are different. With this, it can be inferred that the isn has been degraded. Isonicotinamide is a primary amide exhibiting two strong bands in the region corresponding to the $3361 \mathrm{~cm}^{-1}$ asymmetric, and $3179 \mathrm{~cm}^{-1}$ symmetric stretch of the $v(\mathrm{~N}-\mathrm{H})$ amide group. In addition, the material that crystallized was characteristic of a secondary amide with only one band in the region of $3322 \mathrm{~cm}^{-1}$ referring to $v(\mathrm{~N}-\mathrm{H})[19]$.

The band refers to the angular deformation of isonicotinamide $\delta(\mathrm{N}-\mathrm{H})$ appears at $1621 \mathrm{~cm}^{-1}$; this band is superimposed by the stretches of the amide $v$ 


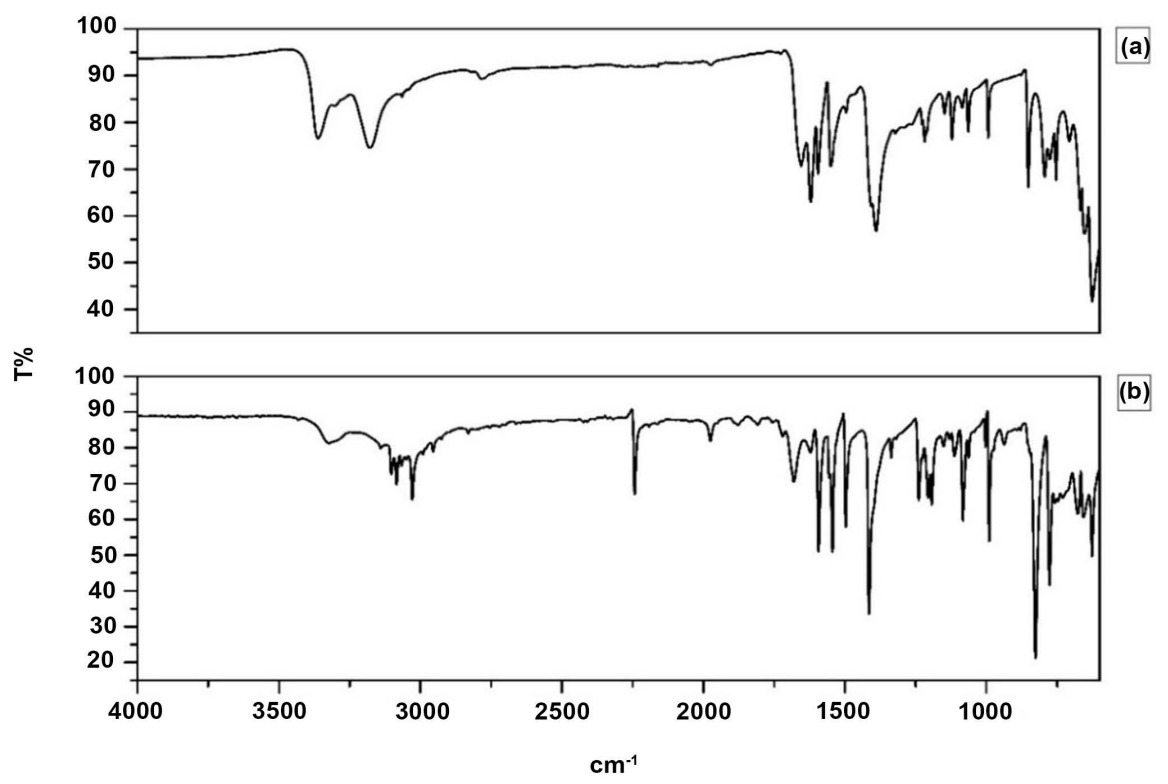

Figure 2. (a) Isonicotinamide; (b) Residue of the flame test.

$(\mathrm{C}=\mathrm{O})$ carbonyl at $1655 \mathrm{~cm}^{-1}$, which in the spectrum appears as doublet. For the flame test, this double-deck behavior is less evident, since the band corresponding to $v(\mathrm{C}=\mathrm{O})$ moved to the region of higher energy, $1681 \mathrm{~cm}^{-1}$, and the band referring to the angular deformation of $\delta(\mathrm{N}-\mathrm{H})$ was maintained at $1621 \mathrm{~cm}^{-1}$. Both bandwidths when compared to free isn, showed is a decrease in intensity that must be attributed to the new structure of this compound. [19]

For the residue, a strong band in the region of $1543 \mathrm{~cm}^{-1}$ is characteristic of a secondary amide and is attributed to the set of stretching $v(\mathrm{C}-\mathrm{N})$ combined with a band of the angular deformation of the $\delta(\mathrm{N}-\mathrm{H})$. With the FTIR analysis of isonicotinamide and the residue, it is possible to conclude that the thermal degradation of isonicotinamide is followed by a hydrogen substitution reaction with the formation of a secondary amide.

It is inferred that the first step of mass loss is attributed to the loss of coordinated water $\left(118^{\circ} \mathrm{C}-155^{\circ} \mathrm{C}\right)$ [11] [20]. The following three stages commenced with the loss of isonicotinamide $\left(170^{\circ} \mathrm{C}-260^{\circ} \mathrm{C} ; 270^{\circ} \mathrm{C}-330^{\circ} \mathrm{C}, 330^{\circ} \mathrm{C}-380^{\circ} \mathrm{C}\right)$ and the last step was the counter-ion output and the $\mathrm{CoO}_{4}$ reduction to $\mathrm{CoO}$ $\left(830^{\circ} \mathrm{C}-930^{\circ} \mathrm{C}\right)[21][22]$.

The Figure 3 demonstrates that for the minimum formula calculations, the total $\Delta \mathrm{m} \%$ was used because it was not possible to determine the stoichiometry of the material using the stepwise $\Delta \mathrm{m} \%$; it is believed that the material loses mass concomitantly. The total empirical $\Delta \mathrm{m} \%$ for the compound is 87.4453 and the calculated $\Delta \mathrm{m} \%$, which matches the synthesized compound, is 87.8544 for stoichiometry $\left[\mathrm{Co}\left(\mathrm{H}_{2} \mathrm{O}\right)(\mathrm{isn})_{3}\right]\left(\mathrm{BF}_{4}\right)_{2}$.

\subsection{Medium FT-IR Infrared Spectroscopy}

Isonicotinamide has three binding sites: the pyridine ring nitrogen, the amide group nitrogen and the carbonyl oxygen [23] [24]. Figure 4 shows the FTIR 

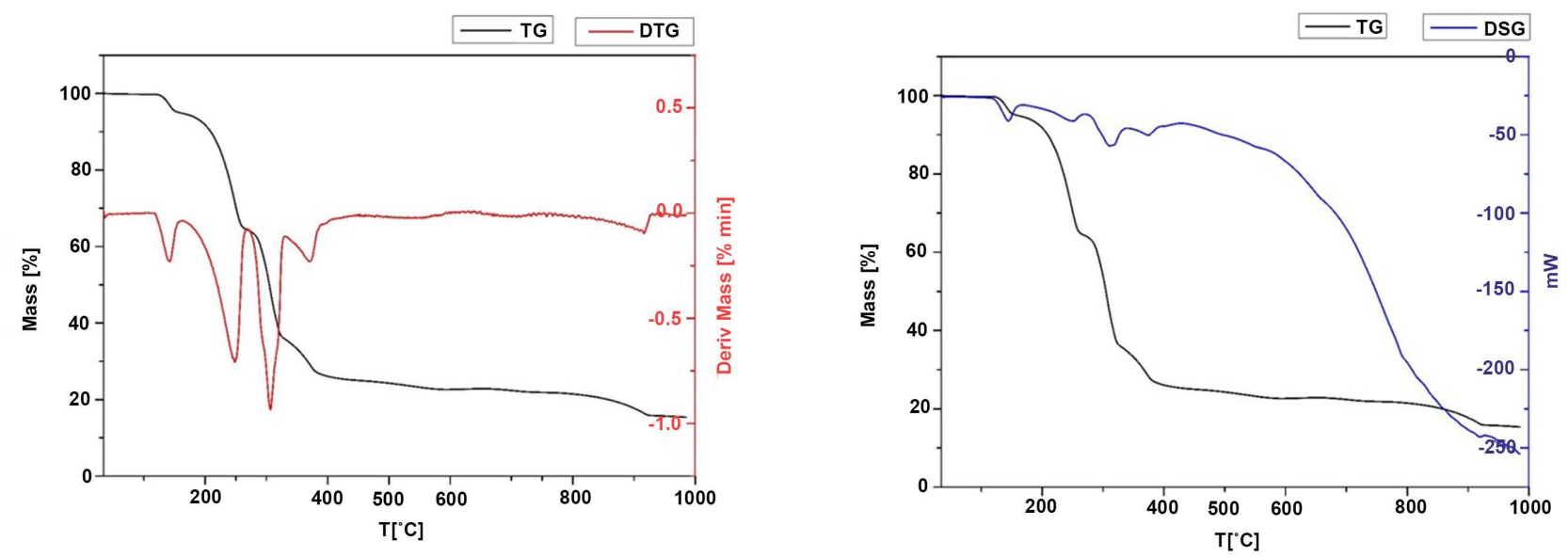

Figure 3. TG-DTG and TG-DSC of $\left[\mathrm{Co}\left(\mathrm{H}_{2} \mathrm{O}\right)_{x}(\mathrm{isn})_{y}\right]\left(\mathrm{BF}_{4}\right)_{z}$.

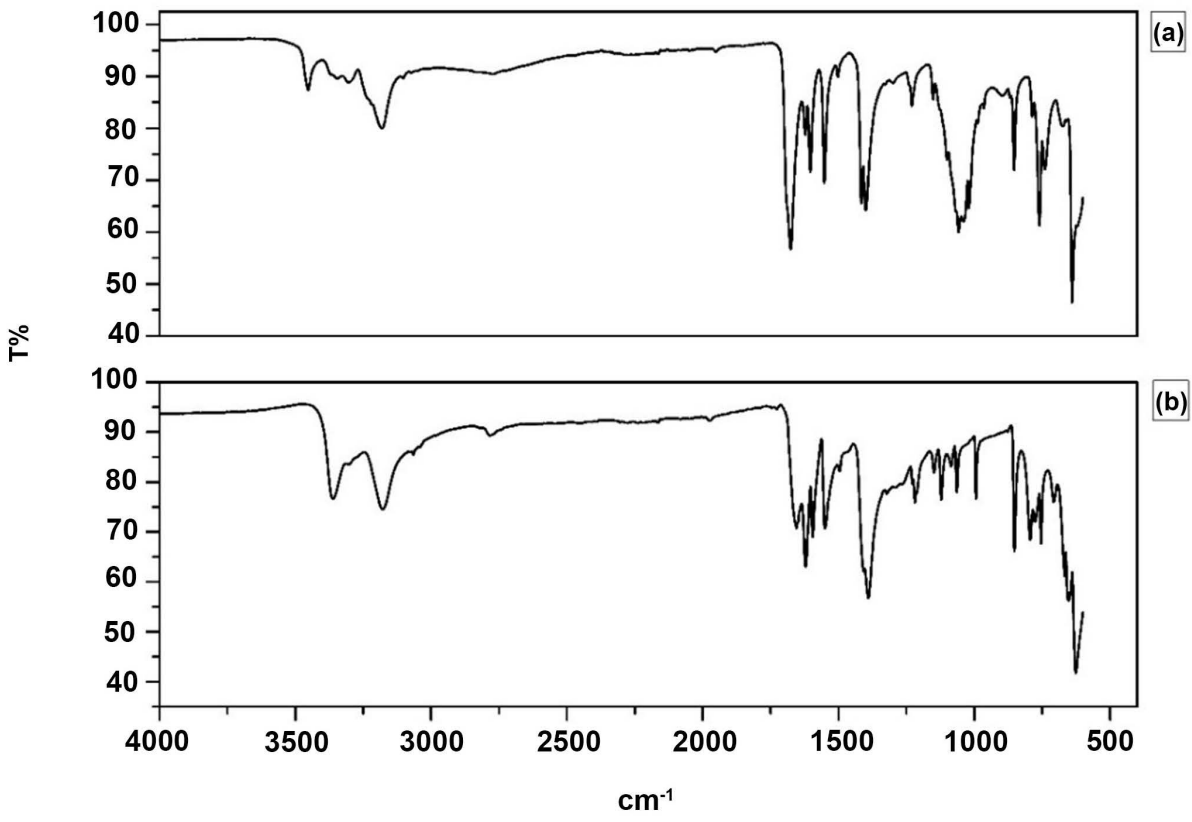

Figure 4. FTIR of (a) $\left[\mathrm{Co}\left(\mathrm{H}_{2} \mathrm{O}\right)(\mathrm{isn})_{3}\right]\left(\mathrm{BF}_{4}\right)_{2}$ and (b) isn.

spectra of the free ligand (isonicotinamide) and the synthesized complex salt $\left[\mathrm{Co}\left(\mathrm{H}_{2} \mathrm{O}\right)(\mathrm{isn})_{3}\right]\left(\mathrm{BF}_{4}\right)_{2}$.

The FTIR spectrum for free isonicotinamide shows bands at 3361, 3303 and $3179 \mathrm{~cm}^{-1}$, which are related to the asymmetric and symmetric stretches of $v$ $(\mathrm{N}-\mathrm{H})$ of the amide group. Peaks in the region 3077 and $3065 \mathrm{~cm}^{-1}$ are attributed to the $v(\mathrm{C}-\mathrm{H})$ stretches of the pyridine ring. Other bands characteristic of free isn are reported at $1621 \mathrm{~cm}^{-1}$, attributed to the angular deformation of $\delta(\mathrm{N}-\mathrm{H})$, and at $1655 \mathrm{~cm}^{-1}$ corresponding to the stretching of the carbonyl of the amide group $v$ $(\mathrm{C}=\mathrm{O})$. A band at $1390 \mathrm{~cm}^{-1}$ refers to the $v(\mathrm{C}-\mathrm{N})$ of the amide and those at 1595 and $994 \mathrm{~cm}^{-1}$ to the stretching of the pyridine ring [23] [25] [26].

Table 2 shows the main vibrational modes in the infrared region for the compound $\left[\mathrm{Co}\left(\mathrm{H}_{2} \mathrm{O}\right)(\mathrm{isn})_{3}\right]\left(\mathrm{BF}_{4}\right)_{2}$, where we can highlight bands in the regions 
Table 2. Main bands observed in the infrared (synthesized compound and ligand).

\begin{tabular}{|c|c|c|}
\hline Ligand (isn) & $\begin{array}{c}\text { COMPLEX } \\
{\left[\mathrm{Co}\left(\mathrm{H}_{2} \mathrm{O}\right)(\mathrm{isn})_{3}\right]\left(\mathrm{BF}_{4}\right)_{2}}\end{array}$ & STRETCH STRATEGIES \\
\hline $3361 \mathrm{~cm}^{-1}(\mathrm{~F})$ & $3453 \mathrm{~cm}^{-1}(\mathrm{~m})$ & $v_{\mathrm{a}}(\mathrm{N}-\mathrm{H})$ \\
\hline $3303 \mathrm{~cm}^{-1}(w)$ & $3304 \mathrm{~cm}^{-1}(\mathrm{w})$ & $v(\mathrm{~N}-\mathrm{H})$ \\
\hline $3179 \mathrm{~cm}^{-1}(\mathrm{~F})$ & $3181 \mathrm{~cm}^{-1}(\mathrm{~F})$ & $v_{\mathrm{s}}(\mathrm{N}-\mathrm{H})$ \\
\hline $3077 \mathrm{~cm}^{-1}(w)$ & $3103 \mathrm{~cm}^{-1}(\mathrm{w})$ & $v(\mathrm{C}-\mathrm{H})$ \\
\hline $3065 \mathrm{~cm}^{-1}(\mathrm{w})$ & $3074 \mathrm{~cm}^{-1}(\mathrm{w})$ & $v_{\mathrm{s}}(\mathrm{C}-\mathrm{H})$ \\
\hline $1595 \mathrm{~cm}^{-1}(\mathrm{~m})$ & $1604 \mathrm{~cm}^{-1}(\mathrm{~m})$ & $v_{\mathrm{s}}$ of ring $(\mathrm{CN})(\mathrm{py})$ \\
\hline $1550 \mathrm{~cm}^{-1}(\mathrm{~m})$ & $1552 \mathrm{~cm}^{-1}(\mathrm{~m})$ & $v_{\mathrm{s}}$ og ring $(\mathrm{CC})(\mathrm{py})$ \\
\hline $1655 \mathrm{~cm}^{-1}(\mathrm{~F})$ & $1676 \mathrm{~cm}^{-1}(\mathrm{~F})$ & $v(\mathrm{C}=\mathrm{O})$ \\
\hline $1621 \mathrm{~cm}^{-1}(\mathrm{~F})$ & $1622 \mathrm{~cm}^{-1}(\mathrm{w})$ & $\delta(\mathrm{N}-\mathrm{H})$ \\
\hline $1407 \mathrm{~cm}^{-1}(\mathrm{~F})$ & $1416 \mathrm{~cm}^{-1}(\mathrm{~F})$ & $v_{\mathrm{a}} \mathrm{CC}(\mathrm{py})$ \\
\hline $1390 \mathrm{~cm}^{-1}(\mathrm{~F})$ & $1400 \mathrm{~cm}^{-1}(\mathrm{~F})$ & $v(\mathrm{C}-\mathrm{N})$ \\
\hline $994 \mathrm{~cm}^{-1}(\mathrm{~m})$ & - & ring contraction (py) \\
\hline - & 965 a $1152 \mathrm{~cm}^{-1}(\mathrm{~F})$ & $v \mathrm{BF}_{4}^{-}$ \\
\hline
\end{tabular}

Stretching (v); Asymmetrical Stretching (va); Symmetrical Stretching $(v s)$; Angular Deformation $(\delta)$; Strong (F); average $(\mathrm{m})$; weak $(\mathrm{w})$.

3453,3304 and $3181 \mathrm{~cm}^{-1}$, the positions and relative intensities of the bands are altered due to the formation of hydrogen bonds between $\mathrm{NH}$, water molecules and counter ion. These interactions can shift the bands to greater or lesser wave numbers [26].

Coordination compounds having amide groups or carbonyl donors show a decrease in the wave number of these groups, indicating that they are coordinated to metals [24] [25]. For the complex, a strong band attributed to the stretches of the group $v(\mathrm{C}=\mathrm{O})$, whereas the angular deformation of the $\delta(\mathrm{N}-\mathrm{H})$ showed a weak band and did not exhibit a relevant variation in wave number. This change is influenced by the hydrogen-bonding dimer of the amide groups [26].

In the literature, compounds of cobalt with isonicotinamide have the nitrogen of the pyridine ring as the binding site, and in the infrared spectra of these compounds, the bands of the ring stretches, 1595 and $994 \mathrm{~cm}^{-1}$, and move to higher energy regions. In the FTIR spectrum of the synthesized complex salt we noted a band in the region of $1604 \mathrm{~cm}^{-1}$, which refers to the stretching of the pyridinium ring (free isn) observed at $994 \mathrm{~cm}^{-1}$ cannot be observed in the compound. Therefore, the coordination of isonicotinamide in the complex must be happening through the ring nitrogen, thus shifting the wave number to a higher energy, and the band referring to the displacement at $993.63 \mathrm{~cm}^{-1}$ is being covered up by a strong and intense band that is attributed to the set of vibrations of the counter-ion $\mathrm{BF}_{4}^{-}$, which moves from 965 to $1152 \mathrm{~cm}^{-1}$ covering all other peaks in this area of the spectrum [25] [26] [27].

Thus, it is proposed that isonicotinamide is coordinated to the metal center through the ring nitrogen and that amide groups are free by hydrogen bonding with other amide groups in the system. 


\subsection{Evaluation of Bactericidal Activity}

The results of the biological activity studies are represented in graphical (Figure 5). In this work, not only was there a concern to demonstrate that the binder isn, when coordinated to the $\mathrm{Co}^{2+}$ metal ion, has a higher bactericidal potential, but also to show the toxicological potential of the metal in its free form.

The reason why these masses are different is that the mole ratio of the separated compounds in the case of $\mathrm{CoCl}_{2}$ and isonicotinamide correspond to the proportions contained in the compound $\left[\mathrm{Co}\left(\mathrm{H}_{2} \mathrm{O}\right)(\mathrm{isn})_{3}\right]\left(\mathrm{BF}_{4}\right)_{2}$, i.e, $1 \mathrm{~mol}$ of complex contains $3 \mathrm{~mol}$ of isn and $1 \mathrm{~mol}$ of $\mathrm{CoCl}_{2}$.

For the $S$. mutans bacterium (Gram + ), the ligand in its free form showed no inhibition halo. However, when the synthesized complex was analyzed, the inhibition diameter was identical to that of the control drug and $25 \%$ smaller than for $\mathrm{CoCl}_{2}$. It is then proposed that, in this case, the metal ion coordinated to isn decreases the permeability of the compound in the bacterium, so decreasing the toxicity of the synthesized compound. Isonicotinamide in its free state showed an inhibition halo 5\% larger than the control material for E. coli. On the other hand, the synthesized compound and $\mathrm{CoCl}_{2}$ presented equal diameters of inhibition, corresponding to twice the activity of gentamicin.

Thus; the active ingredients $\mathrm{CoCl}_{2},\left[\mathrm{Co}\left(\mathrm{H}_{2} \mathrm{O}\right)(\mathrm{isn})_{3}\right]\left(\mathrm{BF}_{4}\right)_{2}$ and isonicotinamide showed distinct results for the $S$. mutans and E. coli bacteria. Perhaps this is due to the difference in the chemical composition of the cell walls of these bacteria. Works by Asegbeloyin et al. [12] and Karekal et al. [28] explain the importance of the metal-binder interaction and how the chelation interferes by reducing the polarity of the central atom, which shares the positive charge with the donor electron-donor groups. This type of interaction increases the lipophilic nature of the metal ion, making it easier to penetrate the cell wall of the bacterium.

This type of interaction is common in many chelated systems where $\pi$ electrons are delocalized on the chelating ring, decreasing the polarity of the metal ion, thereby increasing the lipophilicity of the complexes, preventing the free metal ion from binding to the enzymes contained in the cell wall of the bacteria [12].

Gentamicin is a broad-spectrum antibiotic, i.e., it inhibits strains of Grampositive and -negative bacteria. The interpretation pattern is given by the zone of inhibition in millimeters $(\mathrm{mm})$ and can be classified as resistant $(\leq 12 \mathrm{~mm})$, intermediate $(13-14 \mathrm{~mm})$ or sensitive $(\geq 15 \mathrm{~mm})$. As shown in Figure 5 , inhibition of bacterial growth was observed for all compounds. The only exception was observed for the bacterium $S$. mutans, which is not sensitive to the isonicotinamide ligand, all other compounds tested have been shown to be active.

\section{Conclusion}

Using the set of techniques TG-DTG and TG-DSC, the stoichiometry $\left[\mathrm{Co}\left(\mathrm{H}_{2} \mathrm{O}\right)(\mathrm{isn})_{3}\right]\left(\mathrm{BF}_{4}\right)_{2}$ was proposed for the synthesized compound. Through the FTIR of the binder in its free and complexed form, the binding sites between 


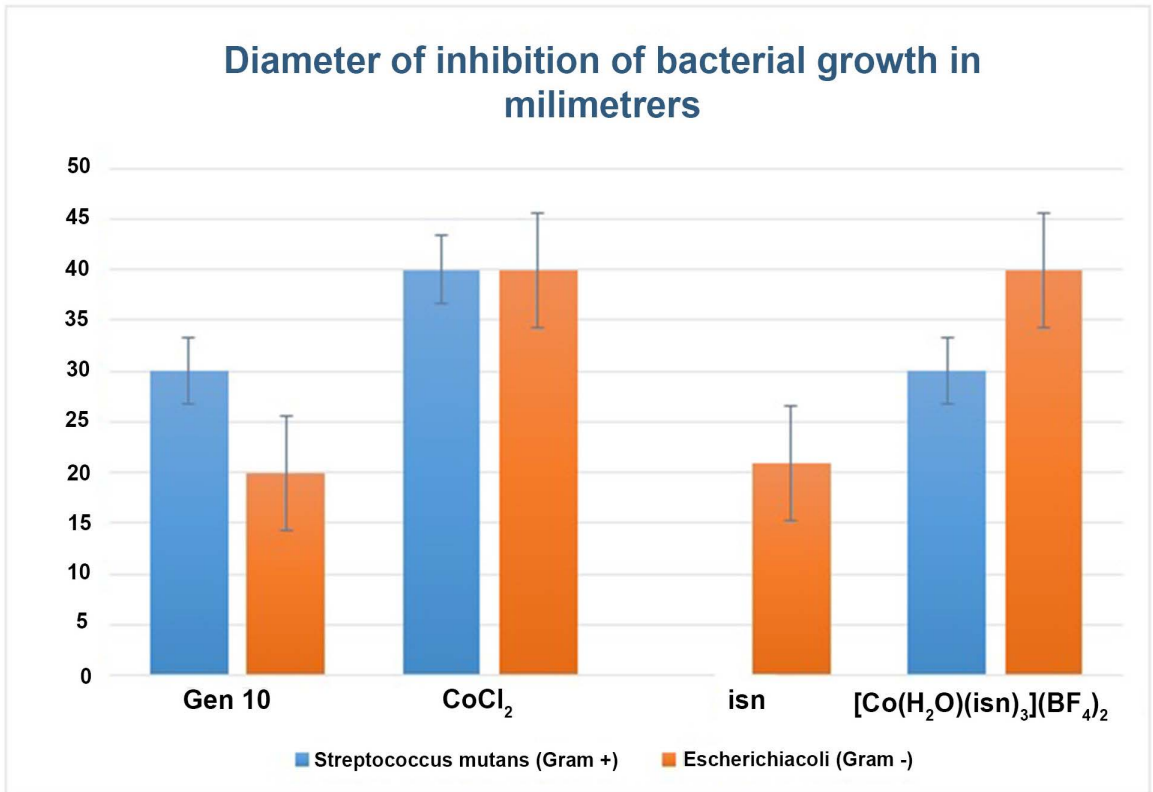

Figure 5. Graph of inhibition diameter of bacterial growth in millimeters.

the isn and the metal ion $\mathrm{Co}^{2+}$ were inferred. It was possible to determine the solubility of the material in hot water and the electrical nature of the synthesized chemical species was presented as a complex salt. The synthesized compound tested for both bacteria was shown to be active as bactericide and may present different action/toxicity depending on the type of bacterium tested.

\section{Conflict of Interest}

The authors declare that there is no conflict of interest regarding the publication of this paper.

\section{Acknowledgements}

Federal University of Mato Grosso (UFMT); Materials Research Lab (MRL); Chronoimmunomodulation Laboratory; FAPEMAT (227937/2015) and CAPES.

\section{Data Availability Statement}

The diameters of the discs (antibiogram) and pasta used to obtain data used to support the findings of this study have been deposited in the figshare repository (DOI 10.6084/m9.figshare.7125065]) and (DOI:10.6084/m9.figshare.7125125)

\section{Conflicts of Interest}

The authors declare no conflicts of interest regarding the publication of this paper.

\section{References}

[1] Demain, A.L. and Sanchez, S. (2009) Microbial Drug Discovery: 80 Years of 
Progress. The Journal of Antibiotics, 62, 5-16. https://doi.org/10.1038/ja.2008.16

[2] Drews, J. (2000) Drug Discovery: A Historical Perspective. Science, 287, 1960-1964. https://doi.org/10.1126/science.287.5460.1960

[3] Rocha, D.P., Pinto, G.F., Ruggiero, R., Oliveira, C.A., Guerra, W., Fontes, A.P.S., Tavares, T.T., Marzano, I.M. and Maia, E.C.P. (2011) Coordenação de metais a antibióticos como uma estratégia de combate à resistência bacteriana. Química Nova, 34, 111-118. https://doi.org/10.1590/S0100-40422011000100022

[4] World Health Organization (2015) Global Action Plan on Antimicrobial Resistance.

[5] Jain, S., Jain, N. and Pitre, K. (2002) Electrochemical Analysis of Sparfloxacin in Pharmaceutical Formulation and Biochemical Screening of Its Co(II) Complex. Journal of Pharmaceutical and Biomedical Analysis, 29, 795-801. https://doi.org/10.1016/S0731-7085(02)00178-4

[6] Lessa, J.A., Reis, D.C., Da Silva, J.G., Paradizzi, L.T., Da Silva, N.F., De Fátima, A.C.M., Siqueira, S.A. and Beraldo, H. (2012) Coordination of Thiosemicarbazones and Bis(thiosemicarbazones) to Bismuth(III) as a Strategy for the Design of Metal-Based Antibacterial Agents. Chemistry and Biodiversity, 9, 1955-1966.

https://doi.org/10.1002/cbdv.201100447

[7] Ogunniran, K.O., Ajanaku, K.O., James, O.O., Ajani, O.O., Nwinyi, O. and Allensela, M.A. (2008) Fe(III) and Co(II) Complexes of Mixed Antibiotics: Synthesis, Characterization, Antimicrobial Potential and Their Effect on Alkaline Phosphatase Activities of Selected Rat Tissues. International Journal of Physical Sciences, 3, 177-182.

[8] Chohan, Z.H., Shaikh, A.U. and Naseer, M.M. (2006) Metal-Based Isatin-Bearing Sulfonamides: Their Synthesis, Characterization and Biological Properties. Applied Organometallic Chemistry, 20, 729-739. https://doi.org/10.1002/aoc.1134

[9] Mohamed, G.G., Omar, M. and Hindy, A.M. (2005) Synthesis, Characterization and Biological Activity of Some Transition Metals with Schiff Base Derived from 2-Thiophene Carboxaldehyde and Aminobenzoic Acid. Spectrochimica Acta Part A: Molecular and Biomolecular Spectroscopy, 62, 1140-1150. https://doi.org/10.1016/j.saa.2005.03.031

[10] Sharaby, C.M. (2007) Synthesis, Spectroscopic, Thermal and Antimicrobial Studies of Some Novel Metal Complexes of Schiff Base Derived from [ $N^{1}-(4-$ Methoxy-1,2,5Thiadiazol-3-yl)Sulfanilamide] and 2-Thiophene Carboxaldehyde. Spectrochimica Acta Part A: Molecular and Biomolecular Spectroscopy, 66, 1271-1278. https://doi.org/10.1016/j.saa.2006.05.030

[11] Çolak, A.T., Çolak, F., Yeşilel, O.Z., Akduman, D., Yılmaz, F. and Tümer, M. (2010) Supramolecular Cobalt(II)-Pyridine-2,5-Dicarboxylate Complexes with Isonicotinamide, 2-Amino-3-Methylpyridine and 2-Amino-6-Methylpyridine: Syntheses, Crystal Structures, Spectroscopic, Thermal and Antimicrobial Activity Studies. Inorganica Chimica Acta, 363, 2149-2162. https://doi.org/10.1016/j.ica.2010.03.007

[12] Asegbeloyin, J.N., Okafor, E.C., Ukwueze, N.N., Babahan, I. and Agbo, I.C. (2014) Synthesis, Characterization and Antimicrobial Screening of Some 4-Acylpyrazoloimines and Some $3 d$ Transition Metal(II) Complexes. Asian Journal of Chemistry, 26, 2753-2758. https://doi.org/10.14233/ajchem.2014.16572

[13] Tawfik, S.M. and Zaky, M.F. (2015) Synthesis, Characterization and Antimicrobial Activity of $N, N$-bis(Hydroxymethyl)- $N$-[(2-Mercaptoacetoxy)Methyl]Alkyl Ammonium Bromide Surfactant and Their Co(II), $\mathrm{Zn}(\mathrm{II})$ and $\mathrm{Sn}(\mathrm{II})$ Complexes. Research on Chemical Intermediates, 41, 7925-7943. https://doi.org/10.1007/s11164-014-1867-3

[14] Carvalho, G.B.D. (2012) Complexos metálicos de cobalto, níquel e cobre com a 
Pirazina-2-carboxamida e 4-hidrazida ácida piridincarboxílica: Síntese e caracterização. Masters Dissertation, Federal University of Rio Grande do Norte, Brazil.

[15] Santos, W.B.D. (2005) Estudo e construção de dispositivos conversores de energia solar em elétrica através de sistemas supramoleculares de rutênio-cromo e rutênio-rutênio. Doctoral Thesis, Federal University of São Carlos, Brazil.

[16] Clsi, E.-A. (2003) Evaluation of the Linearity of Quantitative Measurement Procedures: A Statistical Approach. Approved Guideline, CLSI.

[17] Li, J., Bourne, S.A. and Caira, M.R. (2011) New Polymorphs of Isonicotinamide and Nicotinamide. Chemical Communications, 47, 1530-1532. https://doi.org/10.1039/C0CC04117C

[18] Perpetuo, G.L. (2016) Estudo termoanalítico e caracterização no estado sólido da interação química entre cetoprofeno e alguns compostos orgânicos. Doctoral Thesis, University of Sao Paulo, Brazil.

[19] Pavia, D.L., Lampman, G.M., Kriz, G.S. and Vyvyan, J.R. (2010) Introduction to Spectroscopy. Cengage Learning, Stanford.

[20] Livage, C., Egger, C. and Férey, G. (1999) Hybrid Open Networks (MIL 16): Synthesis, Crystal Structure, and Ferrimagnetism of $\mathrm{Co}_{4}(\mathrm{OH})_{2}\left(\mathrm{H}_{2} \mathrm{O}\right)_{2}\left(\mathrm{C}_{4} \mathrm{H}_{4} \mathrm{O}_{4}\right)_{3} \times 2 \mathrm{H}_{2} \mathrm{O}$, a New Layered Cobalt(II) Carboxylate with 14-Membered Ring Channels. Chemistry of Materials, 11, 1546-1550. https://doi.org/10.1021/cm980781r

[21] Bannach, G., Siqueira, A.B., Ionashiro, E., Rodrigues, E. and Ionashiro, M. (2007) Solid-State Compounds of 2-Chlorobenzylidenepyruvate with Some Bivalent Metal Ions: Synthesis, Characterization and Thermal Behaviour. Journal of Thermal Analysis and Calorimetry, 90, 873-879. https://doi.org/10.1007/s10973-005-7060-6

[22] Caires, F.J., Lima, L.S., Carvalho, C.T. and Ionashiro, M. (2010) Thermal Behaviour of Succinic Acid, Sodium Succinate and Its Compounds with Some Bivalent Transition Metal Ions. Thermochimica Acta, 500, 6-12.

https://doi.org/10.1016/j.tca.2009.11.015

[23] Xue, J., Hua, X., Yang, L., Xu, Y., Li, W., Zhao, G., Zhang, G. and Wu, J. (2013) Spectroscopic Characterization and the Coordination Behavior of Isonicotinamide with Lanthanide Ions. Journal of Molecular Structure, 1052, 93-101.

https://doi.org/10.1016/j.molstruc.2013.08.044

[24] Yurdakul, Ş., Atac, A., Şahin, E. and Ide, S. (2003) Synthesis, Spectroscopic and Structural Studies on Metal Halide Complexes of Isonicotinamide. Vibrational Spectroscopy, 31, 41-49. https://doi.org/10.1016/S0924-2031(02)00066-8

[25] Ataç, A., Yurdakul, Ş. and Ide, S. (2006) Synthesis and Vibrational Spectroscopic Studies of Isonicotinamide Metal(II) Halide Complexes. Journal of Molecular Structure, 783, 79-87. https://doi.org/10.1016/j.molstruc.2005.06.025

[26] Xue, J., Hua, X., Yang, L., Li, W., Xu, Y., Zhao, G., Zhang, G., Liu, L., Liu, K. and Wu, J. (2014) Cobalt(II) and Strontium(II) Complexes of Three Isomers, Nicotinamide, Isonicotinamide and Picolinamide. Journal of Molecular Structure, 1059, 108-117. https://doi.org/10.1016/j.molstruc.2013.11.001

[27] Silva, L.H.M. (1994) Estudo vibracional infravermelho dos compostos tetrafluorborato de potassio, rubidio e cesio: Efeitos isomorficos estruturais no estado solido. Doctoral Thesis, University of Sao Paulo, Brazil.

[28] Karekal, M.R., Biradar, V. and Mathada M.B.H. (2013) Synthesis, Characterization, Antimicrobial, DNA Cleavage, and Antioxidant Studies of Some Metal Complexes Derived from Schiff Base Containing Indole and Quinoline Moieties. Bioinorganic Chemistry and Applications, 2013, Article ID: 315972. https://doi.org/10.1155/2013/315972 